\title{
Errors or identity markers? A survey study on the use of and attitudes towards finlandisms and fennicisms in Finland Swedish
}

\author{
Janine A.E. Strandberg*(i), Charlotte Gooskens $(10$ and Anja Schüppert $(1)$ \\ Center for Language and Cognition Groningen (CLCG), University of Groningen, P.O. Box 716, \\ 9700 AS Groningen, the Netherlands \\ ${ }^{\star}$ Email for correspondence: j.a.e.strandberg@rug.nl
}

(Received 8 February 2021; revised 30 November 2021; accepted 16 December 2021)

\begin{abstract}
This study examines the use of and attitudes towards finlandisms and fennicisms in Finland Swedish. Finlandisms are words or structures typical of the Swedish variety spoken in Finland, while fennicisms are a category of finlandisms for which the source language is Finnish. Fennicisms are often discussed in context of Finnish influence and consequent Finland Swedish language loss, suggesting that the use of these features in Swedish is stigmatised. The study analyses survey responses from 126 Finland Swedish individuals in order to investigate the use of and perceptions regarding fennicisms. The responses indicate that although finlandisms and, in particular, fennicisms are often seen as erroneous, they can also be used to indicate a uniquely Finland Swedish linguistic identity. Additionally, responses regarding fennicisms provide examples of previously overlooked Finnish loanwords, while also indicating that loanwords with origins in other languages are often misidentified as stemming from Finnish. The implications of these findings are discussed.
\end{abstract}

Keywords: Fennicisms; Finland Swedish; finlandisms; identity; language variation; minority languages; sociolinguistics

\section{Introduction}

Early forms of Swedish have been spoken in Finland since at least the 12th century, ${ }^{1}$ with evidence suggesting the presence of Old Swedish-speaking tribes as early as the Viking Age (Häkkinen, 2019:387). From the end of the 19th century onwards, written sources began describing linguistic features specific to the Swedish spoken in Finland, with the most notable early work being Hugo Bergroth's 1917 compilation of instructions on how to avoid Finland Swedish "provincialisms" in speech and writing. Bergroth (1917) argues that, with few exceptions, Finland Swedish should largely follow the standard language norms of Swedish in Sweden 
(Thylin-Klaus, 2019:67). This remains the common approach to the Finland Swedish variety today, as (Central) Standard Swedish is still considered the example upon which Standard Finland Swedish should, to a great extent, be modelled (Reuter, 2015b:12). Bergroth's work also introduced the term finlandssvenska ('Finland Swedish') to the general public, and the word has come to be used widely to refer to both the Swedish variety spoken in Finland, as well as its speakers. Due to the fact that language is the sole most important factor distinguishing the Finland Swedish community from the rest of the Finnish population (af Hällström-Reijonen, 2012:12), the Swedish variety in Finland is often discussed and scrutinised in the public domain as well as by scholars (Reuter et al., 2017:16).

Finland has two national languages, Finnish and Swedish, with 5.2 percent of the country's population (i.e., approximately 290,000 individuals) being registered as native Swedish speakers in 2020 (Statistics Finland, 2021). Whereas the two linguistic groups were historically relatively separate, with monolingual or majority Swedish-speaking communities concentrated along the southern and western coast of Finland, internal migration due to industrialisation and urbanisation in the 20th century has led to increased language contact between Finnish and Finland Swedish speakers (see Tandefelt, 1996; Finnäs, 2015; Strandberg et al., 2021; Strandberg \& Gooskens, in press). Although Finnish and Swedish are both official national languages, and the two linguistic groups have equal rights in Finland, at least half of the Swedish-speaking population today live in Finnish-dominant regions. This factor, combined with the comparatively low number of speakers, means that Swedish in Finland is in practice predominantly confined to Swedish-speaking institutions (Liebkind et al., 2007:3, 6).

As the official standard for the Swedish spoken in Finland has throughout history been Standard Swedish as it is spoken in Sweden, no normative or descriptive standard for the Finland Swedish variety exists (Martola, 1992:516; af Hällström-Reijonen, 2010:103). Regardless, over time a number of phonetic, phonological, syntactic, and lexical features specific to the Finland Swedish variety have emerged. Finland Swedish traditionally lacks the use of pitch accent, which is characteristic of Central Standard Swedish, and a number of vowels and consonants are produced differently in the two varieties (Reuter, 2015b:41-48, 51). Vowel quality has also been shown to be less important in Finland Swedish than in most other Swedish varieties, with qualitative differences between long and short vowels being small or non-existent (Reuter, 1971:246; Kuronen, 2001:96); instead, vowel quantity is crucial in Finland Swedish, with differences in duration of long and short vowels being specifically prominent (Kuronen \& Leinonen, 2001:13; 2011:48-49; Helgason et al., 2010:50; 2013:541-542). Generally, Reuter (1991b) notes that Finland Swedes do not regard Central Standard Swedish as their standard for pronunciation, stating that "nobody would try to imitate it", and that "attempts to do so would be considered ridiculous" (1991b:105). With regards to syntax, examples of typical structures of Finland Swedish include the use of the negation inte at the start of a phrase (e.g., Inte vet jag, 'I don't know') (Lindström, 2009:177). In Standard Swedish, inte almost exclusively follows the verb (i.e., Jag vet inte), and the inverse construction is only used for emphasis.

Lexical features specific to Finland Swedish have been widely discussed within the community, with the term finlandisms (Sw. finlandismer) often being used 
to refer to words or structures specific to the Finland Swedish variety. Finlandisms are words or phrases that are found exclusively in Finland Swedish, or that are used with different meanings than in Standard Swedish (Reuter, 2007:14). The use of these forms is often actively discouraged, particularly in written texts or more formal speech contexts, because they are considered non-standard (af Hällström-Reijonen, 2011:58). A handful of finlandisms may be considered acceptable, due to them filling a gap in the vocabulary; this is the case for words that are typical of Finnish phenomena that are not found in Sweden, such as talko, referring to communal yardwork undertaken by all inhabitants in a neighbourhood, and boboll (lit. 'nest ball'), the name of a Finnish bat-and-ball game (Reuter, 2015b:24). However, the use of certain other types of finlandisms is found particularly problematic by the Swedish language planning entities in Finland. These deviant features are finlandisms that a) have existing equivalents in Standard Swedish; b) have a different meaning than in Standard Swedish; c) have morphology or prepositions which deviate from Standard Swedish; or d) that cannot be understood without knowledge of Finnish (af Hällström-Reijonen, 2011:59; Reuter, 2015b:25-28). Focusing on the latter type, this study seeks to examine the use of and attitudes towards finlandisms amongst Finland Swedish speakers today, with specific attention being paid on the use of fennicisms, i.e., loanwords or calques of Finnish origin.

As a result of longstanding language contact between Swedish and Finnish in Finland, fennicisms are fairly common in Finland Swedish, and they are found in the form of loanwords, loan translations, and semantic loans (af Hällström, 2000:14). Compared to other finlandisms, fennicisms are often found to be particularly problematic (Vikør, 2010:19; Liljestrand, 1985:104). While generally being regarded as non-standard, archaic or dialectal Finland Swedish features may be considered largely inoffensive in informal contexts; fennicisms, by contrast, are usually treated with more reservation by scholars as well as the general public (Martola, 1992:520). Due to the small number of Finland Swedish speakers combined with the widespread dominance of Finnish in society, extensive use of fennicisms is often considered to be a sign of eroding Swedish language skills and, consequently, a direct threat to the Swedish spoken in Finland (Wide \& Lyngfelt, 2009:19). Yet, although a number of studies have examined the use of finlandisms in various written and spoken contexts, very limited research has been conducted on the use of fennicisms in Finland Swedish. Based on survey data from 2019, this study seeks to demonstrate the types of fennicisms that are commonly found in Finland Swedish today, and to discuss the popular attitudes towards these features.

In Section 2 of this article, we first provide an overview of previous research on how Finland Swedes perceive their own variety and their linguistic identity. We then define finlandisms, briefly reporting findings from studies showing how finlandisms have changed through history, and how they are used today. Following this, we move on to discuss fennicisms, in particular their categorisation, and the challenges of studying them. In Section 3, we provide the reader with the methodology of our survey, and we discuss our findings. Much of the Results section focuses on responses to open questions regarding fennicisms (Section 3.2.3) and speaker attitudes about finlandisms and fennicisms in Finland Swedish (Section 3.3). Finally, our Discussion (Section 4) examines the results of our survey in relation to previous research. 


\section{Background}

\subsection{Perceptions regarding Finland Swedish}

The perhaps most comprehensive study on perceptions of Finland Swedish speakers regarding to the status of Swedish in Finland was conducted by Tandefelt (2007). 887 individuals responded to a survey in 2002, answering ten questions regarding language use, e.g., about the status of Swedish in Finland, about Finland Swedish pronunciation and writing, and about the impact of Finnish. The survey questions were displayed as statements, to which participants responded on a five-point Likert scale from 'completely agree' to 'completely disagree' (Tandefelt, 2007:15). On average, the respondents answered 'mostly agree' to the statement "Finland Swedish is a regional variety of Swedish". By comparison, participants mostly disagreed with the statement that Finland Swedish is a language in its own right, but agreed that Finland Swedish should be spoken "with Finland Swedish pronunciation", rather than as Swedish spoken in Sweden (Tandefelt, 2007:19, 26).

The responses to the survey by Tandefelt (2007) suggested that views on Finnish influence on Finland Swedish varied based on age, regional background, and home language(s). On average, participants neither agreed nor disagreed regarding the statement that Finland Swedish is influenced by Finnish; however, participants under the age of 36 reported higher rates of influence of Finnish on their Swedish than older respondends, suggesting a change in language contact compared to previous generations (Tandefelt, 2007:18-19). The results also indicated that speakers from Finnish-dominant regions were less likely to agree with the statement that "Swedish should be spoken in a grammatically correct way", and younger speakers as well as speakers from mixed Finnish- and Swedish-speaking homes were more likely to accept the use of Finnish words in Finland Swedish (Tandefelt, 2007:20,23). However, 72 percent of all participants partially or wholly agreed with the statement that the use of Finnish expressions should be avoided (Tandefelt, 2007:23). By contrast, the responses to similar statements regarding the use of slang and dialectal words and expressions were more lenient. The average response regarding the use of slang was neutral, while attitudes towards dialectal expressions were outright positive, with 70 percent of participants disagreeing with the statement "dialectal words and phrases should be avoided" (Tandefelt, 2007:24).

In an attitude study focusing on child-directed language, Mari Bergroth (2016) examined language use in nine bilingual Finland Swedish and Finnish families. Parents of bilingual children were asked to describe and discuss the terms 'Finnish', 'Swedish' (including 'Finland Swedish' and 'Sweden Swedish'), 'dialect', and 'finlandism' in open interviews (Bergroth, 2016:13). With regards to finlandisms, the author notes that the participants largely address these forms with a sense of obligation. While finlandisms seem to be considered a natural part of Swedish spoken in Finland, they are simultaneously perceived as features that, in principle, should be avoided and controlled (Bergroth, 2016:16). The results indicated that participants perceive finlandisms as features that can be accepted and tolerated as part of the local culture, but only in informal contexts. Some of the parents stated that they try to avoid excessive use of finlandisms around their children, and appreciated that Finland Swedish daycare workers do the same (Bergroth, 2016:17). Bergroth notes that the parents seem to balance between avoiding, accepting, 
and even preferring finlandisms in some contexts, but that mixing of Finnish and Swedish is generally disapproved of (2016:17-18).

The findings from these studies indicate that Finland Swedes perceive their variety as distinct from Swedish spoken in Sweden, and are happy to accept the Finland Swedish pronunciation and even the use of dialectal expressions. Despite the lack of official normative legitimacy of Finland Swedish, Tandefelt (2007) found that speakers' attitudes towards their own variety are largely positive. These results are mirrored in the interview data from Bergroth (2016), which suggest that while parents may try to use more Standard Swedish words around their children for pedagogical reasons, they generally accept and even prefer some Finland Swedish features. On the other hand, direct influence from Finnish was usually avoided by participants in both studies, although younger respondents and respondents from mixed language backgrounds in Tandefelt (2007) were more inclined to accept Finnish words in Finland Swedish. The results by Tandefelt (2007) and Bergroth (2016) thus support the general perception that while some features specific to the Finland Swedish variety may be accepted by the general public, features stemming from Finnish are usually rejected.

\subsection{Finlandisms}

Although phonetic and phonological features are perhaps the most marked features of spoken Finland Swedish when compared to Sweden Swedish (Reuter, 2015a:20), the lexical features referred to as finlandisms have also gathered attention. According to af Hällström-Reijonen (2010:106), finlandisms can be categorised based on various factors, mainly frequency, function, or origin. When analysing finlandisms based on frequency, words can be defined as statistical finlandisms, i.e., words that appear both in Standard Swedish and Finland Swedish, but which are more common in the latter, or absolute finlandisms, which only occur in Finland Swedish. Functional categorisation can differentiate between improper finlandisms (i.e., finlandisms that exist in Finland Swedish due to necessity for a phenomenon typical to Finland, such as talko), or finlandisms that fill a gap in the vocabulary (i.e., words which are not in use in Standard Swedish, despite referring to something not exclusive or typical to life in Finland, such as plåtkrock, a term for car crash with damage only to the vehicle itself) (af Hällström-Reijonen, 2010:107). The third type of categorisation, which divides finlandisms based on origin, sees words defined as archaisms, fennicisms, russicism, germanisms, anglicisms, or as being of local dialectal origin (af Hällström-Reijonen, 2010:106). As the current paper discusses finlandisms influenced by Finnish, we focus on this final type of categorisation.

Due to the fact that they may hinder effective communication between speakers of different varieties of Swedish, as well as contribute to Finland Swedish becoming further removed from the Swedish spoken in Sweden, finlandisms are frequently considered problematic (Reuter, 2015b:12, 31). As such, language cultivation guidelines and recommendations for Swedish language use in Finland tend to consider finlandisms to be non-standard features that should be avoided (Vikør, 2010:19; af Hällström-Reijonen, 2011:57). Regardless of this official position, however, a number of studies have shown that finlandisms in various forms have persistend in all contexts in which Finland Swedish is used. 


\subsubsection{The prevalence of finlandisms}

The effectivity of Finland Swedish language cultivation in eliminating finlandisms from the variety was examined by af Hällström-Reijonen (2010). The study compared the occurrence of finlandisms in newspaper articles from Hufvudstadsbladet from the early and mid-20th century to texts stored in the modern corpus known as the Language Bank of Finland (Språkbanken $i$ Finland). Repeated occurrences of the same finlandisms throughout the century were considered to be signs of unsuccessful language cultivation, i.e., a failure to erradicate the finlandisms from the Finland Swedish lexicon. The study found that the vast majority of finlandisms (49 out of 56) that were used in Hufvudstadsbladet in 1915 were still in use in the 1990s; examples include hämta ('bring with oneself, Sw. ta med sig) and fast ('even though', Sw. även om) (af Hällström-Reijonen, 2010:111). Finlandisms that af Hällström-Reijonen considers having been successfully erradicated from the Finland Swedish vocabulary include bra nog ('almost', Sw. nästan), while words such as the russicism papyross ('cigarette', Sw. cigarett) are still found in literary texts, but not in neutral language contexts (2010: 110-112). The author also notes that the most persistent finlandisms are those that are perceived as Swedish, are stylistically neutral (unlike, for instance, papyross), and, in many cases, those which are supported by corresponding words or expressions in Finnish (af Hällström-Reijonen, 2010:128).

In a 2011 study, af Hällström-Reijonen examined finlandisms appearing in academic speech produced by Finland Swedish individuals. The study examined the occurence of finlandisms in 15 recordings of talks given at three series of seminars in 2005 and 2006 (af Hällström-Reijonen, 2011:62). The speakers consisted of seven women and eight men of various ages, all of whom were academics in the fields of humanities and social sciences. Although finlandisms are generally thought of as features that should not be used in academic contexts, the study showed that the participants seemed to find it difficult to completely avoid them. All participants used some finlandisms in their talks, with the results showing a total of 72 unique finlandisms identified in the 15 recordings and an average frequency of 0.27 finlandisms per minute (af Hällström-Reijonen, 2011:67). While none of the finlandisms were Finnish words, a number of structures seemed to be influenced by Finnish: for instance, the phrase $i$ andra vaningen ('on the second floor') echoes the Finnish inessive (i.e., a locative grammatical case) toisessa kerroksessa (cf. Sw. på andra våningen) (af Hällström-Reijonen, 2011:68). The most common finlandisms were those made up of several words (i.e., phrases, idioms, and prepositional structures), while semantic finlandisms (i.e., words with an extended or altered meaning in Finland Swedish), were the second most frequent type. Lexical finlandisms, which are individual lexemes specific to the variety, were the most infrequent (af Hällström-Reijonen, 2011:76). The infrequency of lexical finlandisms and the absence of fennicisms suggests that these features are the most salient to the speakers, and are thus easiest to avoid (af Hällström-Reijonen, 2011:74).

Investigating change in the use of provincialisms (i.e., non-standard and dialectal forms) over time, Melin-Köpilä (1996) compared a corpus of 289 essays by Finland Swedish elementary and high school students to essays written by students in Sweden. The goal was to examine whether or not provincialisms decreased amongst students as they aged and advanced in education, and if the distributions differed 
between Finland Swedish and Swedish students. Students in both countries were found to use fewer provincialisms in high school than in elementary school, but the Finland Swedish provincialisms (i.e., finlandisms) differed from those in Sweden in that many of them related to Finnish, rather than to Swedish dialects (Melin-Köpilä, 1996:193-194). The study also showed that students from bilingual municipalities used a higher number of finlandisms than their peers from Swedishspeaking environments (Melin-Köpilä, 1996:187). In an effort to examine the use of more "stable" or accepted finlandisms, Melin-Köpilä further investigated Finland Swedish features in texts produced by students at Åbo Akademi University (1996:195). The results indicated that texts written by university students contained notably fewer finlandisms compared to the data from younger students. However, less salient and more standardised finlandisms were still found, indicating that finlandisms can be found in written texts by both young and adult Finland Swedes, regardless of individuals' education or background (Melin-Köpilä, 1996:195-196). Based on these findings, Melin-Köpilä (1996:201) argues that finlandisms can be organised according to an implicit hierarchy, based on how acceptable they are to use and in what context.

The studies above indicate that not only are many finlandisms persistent in the Finland Swedish variety, with finlandisms that were used in 1915 still being used today, but these features are also very widespread. Although the use of finlandisms varies somewhat depending on the age of the individual and the context, it seems that finlandisms are, to some extent, used by all Swedish speakers in Finland, regardless of the factors of age, social class, gender, or education (af Hällström-Reijonen, 2012:4). Finlandisms tend to be well ingrained in Finland Swedish, as they persist in the variety for an extended amount of time, and are generally not specific to individual social groups. Of the various types of finlandisms, however, the previous research suggests that fennicisms are considered more salient and more problematic than other non-standard forms in Finland Swedish.

\subsubsection{Categorising fennicisms}

Fennicisms usually occur as three main types: loanwords, loan translations (i.e., calques), and semantic loans (af Hällström, 2000:14). Previous studies on the use of finlandisms indicate particular avoidance of words of Finnish origin in written texts (Melin-Köpilä, 1996) and academic speech (af Hällström-Reijonen, 2011). On the other hand, individuals seem to find it more problematic to avoid loan translations, semantic loans, and phrases influenced by Finnish (af Hällström-Reijonen, 2011). Although most studies on finlandisms mention fennicisms, they are hardly ever the focus of scholarly interest, and few sources provide extensive examples or explanations of fennicisms in use in Finland Swedish today.

One of the main challenges of studying fennicisms is the ability to define a word as a fennicism, that is, establishing that the direction of borrowing is from Finnish to Swedish. This is particularly true for loan translations and translated phrases. Many words that have a similar or identical form or construction in Finnish and Swedish can be perceived to be fennicisms, but it may be difficult or impossible to establish the relationship between the words. For instance, when discussing the phrase med långa tänder (lit. 'with long teeth', meaning 'to do something with aversion'), 
Table 1. Examples of Finnish loanwords in Finland Swedish, with Standard Swedish corresponding variants and English translations provided ${ }^{3}$

\begin{tabular}{llll}
\hline Finland Swedish & Finnish & Standard Swedish & Translation \\
\hline håsa v. & hosua & jäkta, slarva, skynda & 'to rush, scramble' \\
\hline juttu $\mathrm{n}$. & juttu & sak, historia & 'thing, story' \\
\hline kaamos n. & kaamos & polarnatt & 'polar night' \\
\hline kiva adj. & kiva & rolig, trevlig, kul & 'fun, nice' \\
\hline kokko n. & kokko & bål, brasa & 'bonfire' \\
\hline tavara n. & tavara & sak & 'possession, thing' \\
\hline
\end{tabular}

Reuter (1987b) states that it is difficult to assess whether the Finland Swedish phrase was borrowed from the Finnish pitkin hampain, or the other way around. Although he states that Finnish is likely the origin language, given that the phrase is mainly used in bilingual regions and found exclusively within Finland, the definitive origin remains uncertain (Reuter, 1987b). This difficulty in labelling words as fennicisms is also reflected in how such words and phrases are treated in the Finland Swedish Dictionary (Finlandssvensk ordbok). While an excellent source for finlandisms, the Finland Swedish Dictionary refrains from labelling words as fennicisms: the dictionary only provides cognates or "equivalents" in Finnish (and, occasionally, other languages) when they exist. These equivalents are included as an indication that they often work to conserve and enforce the use of the finlandisms, but they are not to be considered actual etymologies (af Hällström-Reijonen \& Reuter, 2000:264).

Because of the scarce data on fennicisms, the authors of this paper have chosen to define fennicisms in two ways. Many of the examples used, particularly direct loanwords, are established fennicisms, mentioned (often repeatedly) in numerous sources, i.e., Jamrowska (1996); Reuter (1986, 1987a, 1987b, 1989, 1991a, 2015b); af Hällström-Reijonen (2000, 2010, 2012, 2018); as well as the Finland Swedish Dictionary. However, in some cases we make use of loan translations that are not definitively defined as fennicisms, but rather found in the Finland Swedish Dictionary as finlandisms with one-to-one Finnish equivalents. In such cases we presume that the equivalence in form is either due to borrowing from Finnish to Swedish (which, as Reuter (1987b) states, is likely if the form is not found in Sweden), or that the Finnish word has, at the very least, caused the form to remain established in the Finland Swedish lexicon. In Tables 1, 2 and 3 we demonstrate a few common Finnish loanwords, loan translations, and semantic loans used in Finland Swedish.

Direct loanswords from Finnish are common in everyday Finland Swedish, and include nouns as well as adjectives and verbs, e.g., tavara ('possession, thing'), kiva ('nice, fun'), and håsa ('to rush'). These and other examples are demonstrated in Table 1. Finnish loanwords can usually be argued to be very salient; as the majority of Finland Swedes are bilingual to some degree, it is relatively easy for speakers to identify words such as kiva and tavara as stemming from Finnish. Speakers are generally well-aware of lexical fennicisms and finlandisms overall, knowing that 
Table 2. Examples of Finnish loan translations in Finland Swedish, with Standard Swedish corresponding variants and English translations provided. Corresponding parts in Finland Swedish and Finnish compounds words are demonstrated through bold font and underlining

\begin{tabular}{llll}
\hline Finland Swedish & Finnish & Standard Swedish & Translation \\
\hline bakbänk $\mathrm{n}$. & takapenkki & baksäte & 'back seat' \\
\hline franska potatisar $\mathrm{n}$. & ranskalaiset (perunat) & pommes frites & 'fries, chips' \\
\hline mjölkburk $\mathrm{n}$. & maitopurkki & mjölkkartong & 'milk carton' \\
\hline morgonnatten $\mathrm{n}$. & aamuyö & efternatten & 'the small hours' \\
\hline butik(s)kärra $\mathrm{n}$. & kauppakärry & kundvagn & 'trolley' \\
\hline skolning $\mathrm{n}$. & koulutus & utbildning, kurs & 'training, course' \\
\hline
\end{tabular}

Table 3. Examples of Finnish semantic loans in Finland Swedish, with Standard Swedish corresponding variants and English translations provided

\begin{tabular}{llll}
\hline Finland Swedish & Finnish & Standard Swedish & Translation \\
\hline fast adv. & kiinni & stängt, fatt & 'shut, caught' \\
\hline föra v. & viedä & bära, ta med, lämna & 'carry, bring, leave' \\
\hline hamna v. & joutua & bli tvungen & 'have to' \\
\hline hålla v. & pitää & behålla, förvara, ha & 'keep, save, have' \\
\hline söka v. & hakea & hämta & 'fetch' \\
\hline
\end{tabular}

they are considered non-standard, while morphological and syntactic finlandisms are harder to identify and avoid (Tandefelt, 2007:41). As the results of the study by af Hällström-Reijonen (2011) indicated, Finland Swedish speakers often make a conscious effort not to use these types of words in formal situations, or when speaking to Swedish-speakers from Sweden who would not be expected to understand Finnish.

Like direct loans, loan translations or calques are also common in Finland Swedish. Examples of these are included in Table 2. Loan translations appear in everyday words such as bakbänk, which in Finland Swedish refers to the backseat of a car. In Standard Swedish the word for 'back seat' is baksäte, while the Finland Swedish variant corresponds to the Finnish takapenkki, ${ }^{4}$ literally 'back bench'. Speakers may be less aware of using fennicisms in the form of loan translations than loanwords, because the loan translations are not as salient and easily identifiable as individual loanwords (af Hällström-Reijonen, 2011:76). Loan translations also extend to translated phrases or idioms: for instance, many Finland Swedes use the previously mentioned expression med långa tänder, which is not understood in Sweden. It should be noted that, although we refer to all the words in Table 2 as 'Finnish loan translations', it is - as previously mentioned - often difficult to demonstrate that a compound word has originated in one language and later been adopted by the other instead of vice versa. While Reuter $(1989,2015 b)$ has 
attributed the origins of words such as morgonnatten and skolning to Finnish, many other Finland Swedish compound words, including bakbänk and butikskärra, have not received the same attention. Yet, as we argue that association between Finnish and Finland Swedish is evident in the construction of the remaining words, we continue to refer to these words as fennicisms.

The third type of fennicisms, as defined by af Hällström (2000), is the category of semantic loans. Examples of these are included in Table 3. Semantic loans are words (often verbs) which have an extended or altered meaning in Finland Swedish due to influence from Finnish. Like loan translations, semantic loans may be unmarked in Finland Swedish, as the speaker may not even be aware that they are using a fennicism. For instance, many Finland Swedish speakers use the verb söka (lit. 'search, seek'), in the place of Standard Swedish hämta ('fetch') (Reuter, 2005:104).

As Finnish and Swedish have been spoken side by side for centuries, lexical transfer between the two languages is a natural and unavoidable consequence. However, although many fennicisms are quite salient, and lexical borrowings from Finnish into Finland Swedish are widely discussed amongst the Swedish-speaking public in Finland, there is a lack of academic research focusing on the topic. A few researchers have sought to categorise fennicisms and give examples of them (see, in particular, Reuter, 1986; 1987a; 1987b; 1989; 1991a; Jamrowska, 1996), yet no comprehensive resources exist for this specific subtype of finlandisms. This may partially be a result of fennicisms being particularly volatile and region-specific: they may be adopted only by Swedish-speakers in a certain region at a certain time, later falling out of use. Additionally, while other finlandisms are often considered to be irregularities or quirks specific to the Finland Swedish variety, fennicisms are generally viewed more harshly, as substandard features or errors that are compromising the integrity of the Swedish spoken in Finland (Laureys, 2013:238; Wide \& Lyngfelt, 2009:19). Regardless of such negative perceptions, fennicisms are becoming more central to the Finland Swedish vernacular. In the last few generations, the traditionally Swedish-speaking regions in mainland Finland have become more linguistically mixed, with native or early Finnish and Swedish bilingualism increasing amongst the Swedish-speaking population (see Tandefelt, 1996; Tandefelt \& Finnäs, 2007; Strandberg \& Gooskens, in press). With this increased language contact, fennicisms progressively become a more important part of the informal Swedish spoken in Finland (Clyne et al., 2009:128; Jamrowska, 1996:312).

Using a public survey, the current study seeks to identify words and phrases that are in popular use amongst Finland Swedes in the 21st century due to influence from Finnish. We also seek to explore the current attitudes of speakers to both fennicisms and finlandisms in general, to examine how Finland Swedish individuals view and approach such forms in their own variety. We are particularly interested in examining whether fennicisms (or, at the very least, words perceived to be fennicisms) are perceived more negatively compared to other finlandisms, as previous sources would lead us to believe.

There are a number of challenges that must be kept in mind for the present study. As pointed out above, examining the use of fennicisms can be problematic, not only because of the lack of concrete, recurring examples in literature, but also because defining what constitutes a fennicism is not always straightforward. Fennicisms may be very difficult to define or identify, as shown by our examples of loan 
translations; when equivalent words are found in both Finnish and Finland Swedish, it can be difficult or even impossible to definitively pin-point which language originally influenced the other. To complicate matters further, some fennicisms have entered Finland Swedish via Finnish from a different source language, while other words have initially been borrowed to Finnish from Swedish but have remained in Finland Swedish use due to Finnish influence. The latter are sometimes referred to as "ping-pong" loans (Reuter, 2015b:28; Jamrowska, 1996:313). An additional challenge is that, due to the extensive bilingualism amongst Finland Swedes, new Finnish words are constantly being used and consequently borrowed into Finland Swedish everyday speech. This means that while words that are cited as some of the most common fennicisms in earlier literature may still be in use, other, newer fennicisms may be more common at the present time.

\section{The study}

\subsection{Survey}

In order to examine the use of and attitudes towards Finnish influence on Finland Swedish, an online survey was distributed on the social media platform Facebook in the spring of 2019. The survey consisted of open and closed questions. Participants were initially shown examples of finlandisms influenced by or originating from Finnish, and asked to indicate 1) whether they had been exposed to this word or structure before, and 2) whether they used this word or structure themselves. These questions were posed as closed 'yes' or 'no' questions. Following this, participants were asked in open questions to write down examples of words and phrases that 1) they used themselves, or 2) they had heard other people use. After giving responses to the stimuli and providing their own examples, participants were prompted by a final open question to voice any general thoughts they had about the use of Finnish loans and loan translations in Finland Swedish. At the end of the survey, participants were also asked to indicate their native language(s), their regional background within Finland, and their gender.

In the survey, the participants were shown finlandisms that a) stem directly from Finnish; b) have entered Finland Swedish from another language through Finnish, or; c) the use of which can be argued to be stabilised in Finland Swedish due to the corresponding Finnish word. The words were grouped into three different categories, based on whether they were loanwords, loan translations, or translated phrases. The target words are presented in Sections 3.1.1, 3.1.2, and 3.1.3 below. As with the examples in Section 2.2.2, all items were selected based on words and phrases either frequently presented as fennicisms in existing sources (i.e., Jamrowska, 1996; Reuter, 1986; 1987a; 1987b; 1989; 1991a; 2015b; af Hällström-Reijonen, 2000; 2010; 2012; 2018), or as finlandisms with direct Finnish equivalents in the Finland Swedish Dictionary. As research results by af Hällström-Reijonen (2011:69) suggested that finlandisms made up of several words are the most persistent in formal speech by academics, the third category in this study examined the use of translated phrases. The concept of semantic loans was considered to require a significant amount metalinguistic awareness from participants, and was thought to be potentially confusing. Therefore, semantic loans were not included as their own category. 
Table 4. Survey items consisting of loanwords in Finland Swedish, with Finnish, Standard Swedish variants, and English translations provided

\begin{tabular}{llll}
\hline Finland Swedish & Finnish & Standard Swedish & Translation \\
\hline batong $\mathrm{n}$. & patonki & baguette, pain riche & 'baguette' \\
\hline kiva adj. & kiva & rolig, trevlig, kyl & 'fun, nice' \\
\hline palaver $\mathrm{n}$. & palaveri & möte & 'meeting' \\
\hline tjinuski/kinuski $\mathrm{n}$. & kinuski & kola, kolasås & 'caramel sauce' \\
\hline
\end{tabular}

\subsubsection{Loanwords}

The first group of words presented to the survey respondents consisted of four items, either direct loanwords or semantic loans. These are demonstrated in Table 4. The word kiva ('nice, fun') is a direct loan from Finnish into Finland Swedish (Vilppula, 2001). Pronounced [kiva], the Finland Swedish kiva, 'nice', differs from the Standard Swedish verb kiva [ci:va], 'to quarrel'. The word can also be used in compounds, e.g., Det var jättekiva! ('It was really fun!'), and has the established comparative forms kivogare ('more fun') and kivogast ('most fun'). This suggests that the word kiva is a Finnish loanword that is well integrated in the Swedish variety spoken in Finland.

Influence from Finnish does not limit itself to straightforward loanwords or loan translations, but also has an effect of conservation for forms that might otherwise have fallen out of use or been replaced by the Standard Swedish variant (af Hällström, 2012:80). In many cases it can be difficult to definitively assess whether a particular form or meaning has originated in Finnish or Finland Swedish, and from which of the languages it has been borrowed into the other (Melin-Köpilä, 1996:105). Table 4 thus also includes words that have originated in other languages, but which retain their current meaning in Finland Swedish due to parallel use in Finnish. Palaveri ('meeting') entered Finnish through English (from Ancient Greek and Latin via Portugese) (Kotus.fi), and the same neutral meaning has been retained in the Finland Swedish palaver (Finlandssvensk ordbok). Meanwhile, in Standard Swedish, palaver has negative connotations, specifically referring to a disorganised, hectic, and emotional discussion. Thus, palaver in Finland Swedish is semantically connected to the word in Finnish, rather than the Standard Swedish word. This is also the case with the word batong ('baguette'). The "ping-pong" loan, which originated in French bâton ('stick') and was initially borrowed from Swedish into Finnish (Aapala, 1997), continues to be used in Finland Swedish, likely due to the corresponding word patonki in Finnish. In Standard Swedish, however, it has been replaced by baguette or pain riche, while batong now refers to a baton (Mansikka, 2018:24).

A loanword with a more disputed origin is tjinuski [ci'nuski] (alternatively kinuski), which refers to 'fudge' or 'caramel' in English, and as kola in Standard Swedish (Mansikka, 2018:27). For tjinuski/kinuski, the Finland Swedish Dictionary provides the Finnish equivalent kinuski ['kinuski], a word with the same meaning and often identical spelling (Finlandssvensk ordbok). However, although 
Table 5. Survey items consisting of loan translations from Finnish in Finland Swedish, with Standard Swedish variants and English translations provided. Corresponding parts in Finland Swedish and Finnish compounds words are demonstrated through bold font and underlining

\begin{tabular}{llll}
\hline Finland Swedish & Finnish & Standard Swedish & Translation \\
\hline arbetstur $\mathrm{n}$. & työvuoro & arbetspass, -skift & 'shift (at work)' \\
\hline bakbänk $\mathrm{n}$. & takapenkki & baksäte & 'back seat' \\
\hline blomstermylla & kukkamulta & blomjord & 'potting mix' \\
\hline glassboll n. & jäätelöpallo & glasskula & 'scoop of ice cream' \\
\hline motorkälke n. & moottorikelkka & snöskoter & 'snowmobile' \\
\hline skyddsväg n. & suojatie & övergångsställe & 'pedestrian crossing' \\
\hline sakkännare n. & asiantuntija & expert, specialist & 'expert' \\
\hline
\end{tabular}

no Russian equivalent is provided in the Finland Swedish Dictionary, other sources argue that the word is a russicism, stemming from the Russian word тянучки [ ${ }^{\mathrm{j}}{ }_{\mathrm{I}}^{\prime}$ nutck $\mathrm{k}_{\mathrm{I}}^{\mathrm{I}}$ ], meaning 'toffee' or 'fudge' (Sandström \& af Hällström-Reijonen, 2015:128; Thompson, 2009:257). Whether kinuski entered Finland Swedish directly from Russian or through Finnish, it is likely that, as with batong and palaver, the word remained in the Swedish lexicon due to parallel use in Finnish.

\subsubsection{Loan translations}

In addition to four direct loanwords, the survey included seven loan translations or calques. It was estimated that a slightly higher number of example items would be needed for loan translations than loanwords, as loan translations tend to be less salient, and participants were thus expected to be less aware of Finnish calques and likely to volunteer fewer of their own examples. The loan translations used in the survey are listed in Table 5.

All the Finland Swedish words in Table 5 and their Finnish equivalents are included in the Finland Swedish Dictionary, alongside recommendations to avoid these finlandisms and to use the Standard Swedish variants instead. The list includes four compound words in which the latter part is mirrored in the Finnish word, e.g., tur ('turn') in arbetstur, as in Finnish vuoro ('turn, shift'); boll ('ball') in glassboll, as in Finnish pallo ('ball'); mylla ('mulch') in blomstermylla, as in Finnish multa ('mulch, soil'); and bänk ('bench') in bakbänk, as in Finnish penkki ('bench, seat'). In the words sakkännare ('expert'), skyddsväg' ('pedestrian crossing'), and motorkälke ('snowmobile') both parts of the compound words are found in the corresponding Finnish words. It should be noted that while the words arbetstur, skyddsväg, sakkännare, and motorkälke have been previously argued to be Finnish calques (Reuter, 1986; 1989; 1991a; 2015b), no clear etymology has been established for the remaining three words. However, the ways in which the constructions are mirrored in the Finnish and Finland Swedish words gives a strong indication of cross-linguistic influence. 
Table 6. Survey items consisting of translated phrases from Finnish in Finland Swedish, with Standard Swedish variants and English translations provided

\begin{tabular}{llll}
\hline Finland Swedish & Finnish & Standard Swedish & Translation \\
\hline damma mattor & pölyttää mattoja & piska, skaka mattor & 'to dust, shake rugs' \\
\hline falla av kärran & pudota kärryiltä & tappa tråden & 'to lose the plot' \\
\hline i misstag & vahingossa & av misstag & 'by mistake' \\
\hline just och just & juuri ja juuri & nätt och jämt & 'barely' \\
\hline med långa tänder & pitkin hampain & med motvilja & 'reluctantly' \\
\hline påstå i sten & väittää kivenkovaan & påstå bestämt & 'claim adamantly' \\
\hline
\end{tabular}

\subsubsection{Translated phrases}

The final survey items consisted of six Finland Swedish phrases, which can be argued to be either translated from Finnish or strongly influenced by their Finnish counterparts. These are demonstrated in Table 6. Despite the etymologies for these translated phrases remaining unknown or disputed, these Finland Swedish words phrases do appear to be influenced by Finnish, either in their origin or their continued use. As previously mentioned, Reuter (1987b) argues that med langa tänder likely stems from the Finnish phrase pitkin hampain, because the statement is unknown in Standard Swedish and is mostly used in bilingual regions. Similarly, the phrase falla av kärran (lit. 'to fall off the wagon', meaning 'to lose the plot') is the literal equivalent of the Finnish pudota kärryiltä, while påstå $i$ sten (lit. 'to assert in stone) is equivalent to Finnish väittää kivenkovaan (lit. 'to assert stonehard', meaning 'to claim adamantly'). In the final example, $i$ misstag ('by mistake, by accident') only the preposition seems to have been influenced by Finnish. While the preposition av ('by, of, from') would be used in Standard Swedish, in Finland Swedish it is replaced by $i$ ('in'), likely due to influence from the Finnish prepositional inessive ending -ssa (cf. af Hällström-Reijonen's (2011) findings regarding the finlandism $i$ andra våningen).

\subsection{Results}

\subsubsection{Participants}

A total of 126 individuals participated in the survey. The social media platform Facebook was used for spreading the survey, based on previous experience with distributing surveys on the platform and receiving considerable engagement from the target community (Strandberg, 2018). Surveys on social media can easily be considered informal, and they can spread widely since they are easily shared in communities and groups beyond single individuals' social networks. However, the way in which the survey was spread - essentially by word of mouth - is likely to have influenced how the Finland Swedish population was represented in the participant distribution. Of the 126 individuals who participated, 81.7 percent $(N=103)$ reported having only Finland Swedish as their mother tongue, while 15.9 percent $(N=20)$ reported having both Finland Swedish and Finnish as their native languages. 2.4 percent $(N=3)$ reported having Finland Swedish and another 
Table 7. Summary of survey responses $(N=126)$ indicating number and percentage of participants who recognise and use selected loanwords in Finland Swedish

\begin{tabular}{lccccc}
\hline & \multicolumn{2}{c}{ Recognition } & & \multicolumn{2}{c}{ Active use } \\
\cline { 2 - 3 } \cline { 5 - 6 } Loanword & $\%$ & & & $\%$ & $\mathrm{~N}$ \\
\hline batong & 90.5 & 114 & & 79.2 & 99 \\
\hline kiva & 99.2 & 125 & 84.0 & 105 \\
\hline palaver & 90.5 & 114 & 63.2 & 79 \\
\hline tjinuski/kinuski & 95.2 & 120 & 82.4 & 103 \\
\hline
\end{tabular}

language as their native languages. 73.0 percent $(N=92)$ of the survey respondents identified as women, and 26.2 percent $(N=32)$ identified as men, while 0.8 percent $(N=1)$ of participants chose not to disclose their gender. The unbalanced number of male versus female participants mirrors that of Tandefelt (2007:10), who also reported that 67 percent of participants in her survey were women, and is in line with previous findings suggesting female participants are more likely to respond to online surveys (see, for instance, Smith, 2008). The regional background of survey participants was also unevenly distributed, with 66.7 percent of participants $(N=84)$ hailing from the region of Nyland (Fi. Uusimaa) in Southern Finland. The second largest group of 11.1 percent $(N=14)$ came from Ostrobothnia (Sw. Österbotten, Fi. Pohjanmaa), followed by 7.9 percent $(N=10)$ from Finland Proper (Sw. Egentliga Finland, Fi. Varsinais-Suomi). This may be partially explained by the population distribution, as approximately 46 percent (132,760 individuals) of all Finland Swedish speakers were reported to live in Nyland in 2017 (Kuntaliitto.fi; Statistics Finland, 2021). ${ }^{6}$

\subsubsection{Recognition and use of finlandisms}

With regards to the loanwords presented to participants, a very high recognition rate ( $>90.5$ percent) was reported for all words. The responses to these words are summarised in Table 7. The highest percentages for both recognition and use were reported for the adjective kiva, with as many as 99.2 percent of participants recognising the word, and 84 percent reporting actively using it. Only one participant indicated not being familiar with kiva. These results are unsurprising, considering the widespread use of kiva in the Finland Swedish vernacular and its status of a classic or stereotypical Finland Swedish word. The second most commonly used and recognised word was tjinuski/kinuski: 95.2 percent of participants said they recognised the word, and 82.4 percent stated that they themselves used it. For both batong and palaver, 90.5 percent of participants reported having heard the word, but only 63.5 percent reported using palaver, while 79.2 percent reported using batong.

As with the loanwords, participants indicated to what extent they recognised and used loan translations and translated phrases from Finnish. Table 8 shows that, with regards to loan translations, participants reported a high $(>80 \%)$ recognition rate for the majority of words, with the exception of blomstermylla (69\%) and sakkännare (57.9\%). The lowest rates of active use also corresponded with lowest 
Table 8. Summary of survey responses $(N=126)$ indicating number and percentage of participants who recognise and use selected Finnish loan translations

\begin{tabular}{lccccc}
\hline & \multicolumn{2}{c}{ Recognition } & & \multicolumn{2}{c}{ Active use } \\
\cline { 2 - 3 } \cline { 5 - 6 } Loan translation & $\%$ & & & $\%$ & $\mathrm{~N}$ \\
\hline arbetstur & 82.5 & 104 & & 62.7 & 79 \\
\hline bakbänk & 81.7 & 103 & 60.3 & 76 \\
\hline blomstermylla & 69.0 & 87 & 34.1 & 43 \\
\hline glassboll & 91.3 & 115 & 84.1 & 106 \\
\hline motorkälke & 81.0 & 102 & 56.3 & 71 \\
\hline skyddsväg & 93.7 & 118 & 84.9 & 107 \\
\hline sakkännare & 57.9 & 73 & 27.0 & 34 \\
\hline
\end{tabular}

Table 9. Summary of survey responses $(N=126)$ indicating number and percentage of participants who recognise and use selected translations of Finnish phrases in Finland Swedish

\begin{tabular}{lccccc}
\hline & \multicolumn{2}{c}{ Recognition } & & \multicolumn{2}{c}{ Active use } \\
\cline { 2 - 3 } \cline { 5 - 6 } Phrase & $\%$ & & & $\%$ & $\mathrm{~N}$ \\
\hline damma mattor & 93.7 & 118 & 76.2 & 96 \\
\hline falla av kärran & 54.0 & 68 & 28.6 & 36 \\
\hline i misstag & 94.4 & 119 & 82.5 & 104 \\
\hline just och just & 97.6 & 123 & 86.5 & 109 \\
\hline med långa tänder & 78.6 & 99 & 51.6 & 65 \\
\hline påstå i sten & 16.7 & 21 & 7.9 & 10 \\
\hline
\end{tabular}

rates in recognition, as only 34.1 percent of participants reported using blomstermylla, with as few as 27 percent using sakkännare. The most commonly used loan translations were skyddsväg and glassboll, as both were reportedly recognised by 93.7 and 91.3 percent of participants, and used actively by 84.9 and 84.1 percent, respectively.

In comparison to loanwords and loan translations, the results indicate greater variation in the use of translated phrases, as shown in Table 9. Some phrases were deemed very common, with a recognition percentage of above 90 percent, i.e., just och just, i misstag, and damma mattor. Out of these, just och just and $i$ misstag were reportedly used actively by over 80 percent of the survey participants. By contrast, the phrase påstå $i$ sten was only recognised by 16.7 percent of the respondents, and actively used by 7.9 percent $(N=10)$. It could be argued that if speakers use a version of the phrase that is an exact equivalent of the Finnish väittää kivenkovaan, the Finland Swedish phrase would rather be påstå stenhårt, which might explain the low recognition for påstå $i$ sten. However, påstå stenhårt is also unlikely to be very established in the variety, given that it is not included in the Finland Swedish Dictionary, nor were the authors able to find it in other sources. 
It is interesting to note that for all types of Finland Swedish features that were investigated in the study, the survey participants consistently reported considerably higher percentages of having heard and recognising the individual words and phrases, compared to actively using them. However, due to the nature of the survey, it is difficult to asses the accuracy of respondents' self-reported use versus their exposure to the items. Based on the survey alone, it is unclear to what extent participants may under-report their own use of finlandisms and, in particular, fennicisms, due to the stigma related to using non-standard Swedish.

\subsubsection{Open questions}

After being asked to indicate their recognition of and active use of the finlandisms provided in the survey, the participants were asked to provide their own examples of loanwords, calques, and translated phrases from Finnish. The responses are summarised in Table 10.

A total of 66 unique loanwords were obtained through the survey. Out of these, 18 words were only included a single time. For the purpose of this study, we consider loanwords that were repeated more than once to be more relevant, as repetition by several independent individuals suggest that a loanword is in wider use in the Finland Swedish community, rather than simply being a feature of one person's idiolect. Regardless, loanwords that only appear once in the survey reponses should not be completely disregarded, given that some of the "stereotypical" fennicisms in Finland Swedish, such as the previously mentioned kokko ('bonfire'), are only found once in the open responses. Furthermore, it should be noted that as these loanwords in Finland Swedish are not standardised, the responses show numerous instances of variation in spelling, for example in the case of words such as halare/haalare ('overall') and pajto/pajta ('shirt').

In their reponses, participants mentioned some frequent stereotypical examples of Finnish loanwords (e.g., aula, kaamos, kokko), as well as other words noted mentioned in earlier sources, such as juttu ('thing, story'), keikka ('concert, gig'), kurabyxor ('rain trousers'), and kaveri ('friend') (see Bergroth, 2016; Liljestrand, 1983; 1985). Additionally, the survey data indicated a wider use of direct Finnish loanwords in Finland Swedish than previous literature suggests. Some of the most common items included nouns such as kännykkä ('cell phone'), and kaukosäädin ('remote control'). Adjectives and adverbs, such as hurja, ('very, cool, fierce'), or siisti ('cool') were also common, as were compound words where half of the word is borrowed, e.g., pipomössa ('beanie, hat').

The majority of responses provided examples of finlandisms that are clearly fennicisms, i.e., loanwords that stem directly from Finnish, such as juttu ('thing, story') or maila ('bat, club'). However, a number of the words provided were words that have similar forms and meaning in Finnish and Finland Swedish, but which have a different or disputed origin. The majority of these items are words which have likely remained active in Finland Swedish due to the conserving effect of parallel use in Finnish. These words and their etymologies are included in Table 13 in the Appendix. A word frequently identified as a Finnish loanword was the greeting moj, meaning 'Hi, Hello'. Moj (and its variants moi, mojn, and morjens) was mentioned eight times as an example of a fennicism in Finland 
Table 10. Survey responses of Finnish loanwords in Finland Swedish, with Standard Swedish equivalents and English translations

\begin{tabular}{|c|c|c|c|c|}
\hline Finland Swedish & $\mathrm{N}$ & Finnish & Standard Swedish & Translation \\
\hline acku, akku n. & 4 & akku & batteri & 'battery' \\
\hline aula $\mathrm{n}$. & 2 & aula & entréhall & 'entry hall' \\
\hline batteri $\mathrm{n}$. & 7 & patteri & element & 'heater' \\
\hline butka $n$. & 1 & putka & finka & 'jail, prison’ \\
\hline chokopatukka n. & 2 & suklaapatukka & chokladbit & 'chocolate bar' \\
\hline farkku-, farkkur adj., n. & 2 & farmarit, farkut & jeans & 'jeans' \\
\hline halare, haalare $\mathrm{n}$. & 6 & haalari & overall & 'overalls' \\
\hline harma v. & 2 & harmittaa & reta, irritera & 'vex, irk’ \\
\hline (i) hukka adv. & 1 & hukkaan & kasta/tappa (bort) & 'waste(d), lost' \\
\hline hurja adj, adv. & 11 & hurja & tuff, cool & 'wild, cool' \\
\hline hyvä adj. & 1 & hyvä & bra & 'good' \\
\hline hätä n. & 2 & hätä & problem & 'problem, concern' \\
\hline juttu $n$. & 5 & juttu & sak, historia & 'thing, item, story' \\
\hline jännä adj. & 3 & jännä & spännande & 'strange, interesting' \\
\hline kaamos $\mathrm{n}$. & 1 & kaamos & polarnatt & 'polar night' \\
\hline kalja n. & 1 & kalja & öl & 'beer' \\
\hline kalvo $\mathrm{n}$. & 1 & kalvo & film, hinna & 'film, sheet' \\
\hline kaman $\mathrm{n}$. & 1 & kamat & saker & 'things, possessions' \\
\hline karkki n. & 6 & karkki & godis & 'candy, sweets' \\
\hline katiska n. & 2 & katiska & mjärd, katsa & '(cray)fish trap' \\
\hline kauhee adj., adv. & 2 & kauhea & mycket, hemsk(t) & 'very, horrible' \\
\hline kaukosäädin n. & 3 & kaukosäädin & fjärrkontroll & 'remote control' \\
\hline kaveri $\mathrm{n}$. & 5 & kaveri & vän & 'friend' \\
\hline keikka n. & 3 & keikka & konsert & 'gig, concert' \\
\hline kina v. & 2 & kinata & gräla & 'argue, fight' \\
\hline kokko n. & 1 & kokko & bål, brasa & 'bonfire' \\
\hline kontti $n$. & 1 & kontti & container & 'container, trunk' \\
\hline krapula n. & 3 & krapula & baksmälla & 'hangover' \\
\hline kurabyxor $n$. & 5 & kurahousut & galonbyxor & 'rain trousers' \\
\hline kurakläder $\mathrm{n}$. & 2 & kuravaatteet & galonkläder & 'rain clothes' \\
\hline kuri $\mathrm{n}$. & 1 & kuri, kurittaa & disciplin & 'discipline' \\
\hline kännykkä n. & 7 & kännykkä & mobil(telefon) & 'cell phone' \\
\hline leffa $n$. & 3 & leffa & film, bio & 'movie, cinema' \\
\hline
\end{tabular}


Table 10. (Continued)

\begin{tabular}{|c|c|c|c|c|}
\hline Finland Swedish & $\mathrm{N}$ & Finnish & Standard Swedish & Translation \\
\hline lippis $n$. & 4 & lippis, lippalakki & keps & 'baseball cap' \\
\hline löyly n. & 2 & löyly & (kasta) bad & 'steam (in sauna)' \\
\hline maila, majla $\mathrm{n}$. & 4 & maila & klubba, racket & 'bat, club' \\
\hline makee adj. & 4 & makea & tuff, cool & 'cool, sweet' \\
\hline moj, mojn, moi excl. & 8 & moi, moro, moikka & hej, hejsan & 'Hi, Hello' \\
\hline mjölktölk n. & 2 & maitotölkki & mjölkkartong & 'milk carton' \\
\hline moittar v. & 1 & moittia & klandra & 'reprimand' \\
\hline mono $\mathrm{n}$. & 4 & mono & pjäksa, skidsko & 'skiing boot' \\
\hline mopo $n$. & 3 & mopo & scooter & 'scooter' \\
\hline mössö n., adj. & 2 & mössö & smet, kladd & 'goo, gooey' \\
\hline muta $n$. & 2 & muta & lera & 'mud' \\
\hline paha adj. & 4 & paha & dålig & 'bad' \\
\hline pajto, pajta n. & 2 & paita & skjorta & 'shirt' \\
\hline piimä n. & 2 & piimä & surmjölk & 'buttermilk' \\
\hline pipo, pipomössa n. & 4 & pipo & luva, mössa & 'beanie, hat' \\
\hline pito $n$. & 1 & pito & (väg)grepp & 'hold, grip' \\
\hline pulka, pulkka n. & 2 & pulkka & släde, pulka & 'sled' \\
\hline puukko $\mathrm{n}$. & 2 & puukko & kniv & 'knife' \\
\hline päikkäre $\mathrm{n}$. & 2 & päikkäri & tupplur & 'nap(time)' \\
\hline remont $\mathrm{n}$. & 2 & remontti & renovering & 'refurbishing' \\
\hline rosk, roskis n. & 54 & roska, roskis & skräp, sopor & 'trash, garbage' \\
\hline semla $n$. & 1 & sämpylä & fralla & 'bread roll' \\
\hline siisti adj. & 5 & siisti & tuff, cool & 'cool, awesome' \\
\hline spåra n. & 1 & spora & spårvagn & 'tram' \\
\hline stöpsel $n$. & 1 & töpseli & (stick)kontakt & 'electric chord' \\
\hline suti sutia n., v. & 1 & sutia & glida, slira & 'glide, slide' \\
\hline talko $\mathrm{n}$. & 1 & talko & arbetsgästabud & 'communal work' \\
\hline tarkka adj. & 2 & tarkka & noga, exakt & 'precise, exact' \\
\hline tarra n., v. & 3 & tarra, tarrautua & klistermärke & 'sticker, stick' \\
\hline tavara $\mathrm{n}$. & 3 & tavara & sak & 'thing, item' \\
\hline toima, toimar v. & 2 & toimii, toimiva & fungera, fungerar & 'work, working' \\
\hline vessa $n$. & 15 & vessa & toa, toalett & 'toilet' \\
\hline ämbar n. & 1 & ämpäri & hink & 'bucket' \\
\hline
\end{tabular}


Swedish, likely due to it being used as a greeting in Finnish as well; in Finnish it is commonly used as moi, moro, or moikka. Although the origins of moj and mojn in Finland Swedish (and, consequently, Finnish) are debated, the greeting is usually thought to stem from Swedish morgon (Kolehmainen, 2007). ${ }^{7}$

While the actual origin of a finlandism may be masked by parallel use in Finnish, the same was found for a number Swedish archaisms or Finland Swedish dialectal words, which were identified by respondents as having Finnish roots. The example which was most often mentioned as a fennicisms was the word rosk or roskis ('trash, garbage'). The word is widely known to be a finlandism, as in Standard Swedish the words avfall, sopor, and skräp are used instead. In the open responses in the survey the word rosk, roskis was mentioned 54 times as a fennicism, making it by far the most common item representing a Finnish borrowed word or phrase in Finland Swedish. However, although the words is often thought to originate in Finnish, where it exists as roska, research indicates that roska has originally been borrowed to Finnish from Swedish: the root of rosk is Norse, as its cognates can be found in the Norwegian or Faroese word rusk (af Hällström, 2018). Therefore, rosk is an example of a "ping-pong" loan, which has been borrowed from Swedish to Finnish and then back again. Like the survey example batong, the word rosk has retained its use and meaning in Finland Swedish due to the use of the word in Finnish as well, while the word has disappeared from Standard Swedish.

Overall, participants were far more likely to provide their own examples for direct Finnish loanwords than for loan translations or phrases. The 126 participants provided 66 unique examples of (perceived) loanwords, compared to only 15 examples of loan translations and seven examples of translated phrases. Table 11 demonstrates the 15 loan translations provided by the survey participants. Only six words were included in responses by more than one participant; the words chokladplatta (alternatively spelled chokoplatta) and taltur were included in three responses each, while chokladstång, skolning, hönshud, and bilringar were all included twice.

A number of the compound words, namely bilring, brödrot, hönshud, are not identified as finlandisms in the Finland Swedish Dictionary, nor are they found in the Swedish Academic Dictionaries (Svenska.se). On the other hand, bilskola and dragkedja are both found in the Swedish Academic Dictionaries alongside their Standard Swedish synonyms trafikskola and blixtlås; however, it should be noted that the participant who included dragkedja may have confused it with the form dragked, as the latter is considered a finlandism (Äikäs, 2012; Finlandssvensk ordbok). With regards to egnahemshus, both Reuter (2015b:203) and the Finland Swedish Dictionary mention the word as a non-standard term for a detached house (referred to as villa in Standard Swedish), but neither discuss it in relation to the Finnish omakotitalo. Nevertheless, as the three words dragked(-ja), bilskola, and egnahemshus have the same morphology as their Finnish equivalents, it is easy to see how the Finnish word may have encouraged the use of the Finland Swedish variant, and how speakers may perceived them as fennicisms.

The respondents provided the fewest number of examples for translated phrases in Finland Swedish, with the vast majority indicating that they could not think of an example. The results from the open question for Finnish translated phrases are shown in Table 12. Out of the seven phrases provided by the respondents, only two were included by more than one participant: helt samma and sist och slutligen. 
Table 11. Survey responses of Finnish loan translations in Finland Swedish, with Standard Swedish equivalents and English translations. Corresponding parts in Finland Swedish and Finnish compounds words are demonstrated through bold font, underlining, and italic font

\begin{tabular}{|c|c|c|c|c|}
\hline Finland Swedish & $\mathrm{N}$ & Finnish & Swedish & Translation \\
\hline bilstall $n$. & 1 & autotalli & garage & 'garage' \\
\hline bilskola n. & 1 & autokoulu & kör-, trafikskola & 'driving school' \\
\hline bilringar $\mathrm{n}$. & 2 & autonrenkaat & bildäck & '(car) tyres' \\
\hline brödrot $n$. & 1 & leipäjuuri & surdeg & 'sourdough' \\
\hline dragkedja $n$. & 1 & vetoketju & blixtlås & 'zipper' \\
\hline egnahemshus n. & 1 & omakotitalo & villa & 'detached house' \\
\hline chokladplatta $\mathrm{n}$. & 3 & suklaalevy & chokladkaka & 'chocolate slab' \\
\hline chokladstång $\mathrm{n}$. & 2 & suklaapatukka & chokladbit & 'chocolate bar' \\
\hline egenläkare $n$. & 1 & omalääkäri & husläkare & 'general practitioner' \\
\hline hönshud n. & 2 & kananliha & gåshud & 'goosebumps' \\
\hline knackkorv $n$. & 1 & nakkimakkara & knackwurst, varmkorv & 'frankfurter' \\
\hline morgonlänk $n$. & 1 & aamulenkki & morgonrunda & 'morning jog' \\
\hline skolning $\mathrm{n}$. & 2 & koulutus & kurs & 'course' \\
\hline taltur $\mathrm{n}$. & 3 & puheenvuoro & att ha ordet & 'turn to speak' \\
\hline Vändagen $\mathrm{n}$. & 1 & Ystävänpäivä & Alla hjärtans dag & 'Valentine's Day' \\
\hline
\end{tabular}

Table 12. Survey responses of Finnish translated phrases in Finland Swedish, with Standard Swedish equivalents and English translations

\begin{tabular}{lllll}
\hline Finland Swedish & $N$ & Finnish & Swedish & Translation \\
\hline bli i backen & 1 & jäädä mäkeen & stanna i backen & 'get stuck uphill' \\
\hline helt samma & 2 & aivan sama & ngt är obetydligt & 'no matter' \\
\hline längs med dagen & 1 & pitkin päivää & hela dagen & 'throughout the day' \\
\hline nippanappa & 1 & nippa nappa & nätt och jämt & 'barely' \\
\hline på sätt eller annat & 1 & tavalla tai toisella & på ett eller annat sätt & 'one way or the other' \\
\hline sist och slutligen & 2 & loppujen lopuksi & trots allt & 'in the end' \\
\hline som knytnäven i ögat & 1 & kuin nyrkki silmään & passa perfekt & 'to fit like a glove' \\
\hline
\end{tabular}

The fact that the survey respondents provided comparatively few items of loan translations and translated phrases supports the theory that these features are not only less common, but also less marked and less salient in Finland Swedish than direct loans. 


\subsection{Attitudes}

In addition to being asked to provide examples of fennicisms that they themselves used, the participants were prompted to give their own opinions regarding the use of Finnish loans or loan translations in Finland Swedish. As it was not mandatory to answer this question in order to complete the survey, the majority of respondents either left the question blank or responded that they had nothing specific to add. Of the respondents who wished to voice their thoughts on the use of fennicisms in Finland Swedish, four participants wished to make it clear that although they were familiar with some or even all of the example fennicisms, they avoided or never used fennicisms themselves. Examples 1 and 2 show two of these responses, which tended to be short and not include elaborations. Other participants, however, were somewhat more conflicted on the topic. Example 3 shows the response of a participant who stated that they considered it a pity that fennicisms are used so often in Finland Swedish, and wondered if this was one of the reasons for "the declining quality of Swedish in Finland".

1. Använder inga. Undviker översättningslån medvetet.

[I] don't use any. [I] consciously avoid loan translations. (Monolingual male, Ostrobothnia)

2. Undviker låneord.

[I] avoid loanwords.

(Monolingual female, Nyland)

3. Egentligen är det synd att vi använder dem så aktivt för det kan vara en orsak till varför kvalitén av svenskan har sjunkit i Finland. Å andra sidan kan de kanske hjälpa språket utvecklas vidare.

Actually, it's a pity that we use them so actively, because that can be a reason for the declining quality of Swedish in Finland. On the other hand, it may perhaps help the language develop.

(Monolingual female, Nyland)

Although the response in Example 3 indicates a primarily negative view of fennicisms in Finland Swedish, the participant also hypothesises that these features may help develop the language. Other responses included more overtly positive comments regarding the use of Finnish loanwords or calques in Finland Swedish. Example 4 shows the response from a participant who considers loanwords acceptable in Finland Swedish, as long as the loanwords and phrases are used with "correct Swedish conjugation".

4. Rätt använda (alltså böjda på svenska) berikar de språket. Fel använda (böjda på finska eller finska ord som inte brukar användas på finlandssvenska) gör de språket sämre.

Used correctly (i.e., conjugated in Swedish) they enrich the language. Used incorrectly (conjugated in Finnish or Finnish words that are not usually used in Finland Swedish) they impair the language.

(Monolingual male, Nyland)

Five other participants also stated that fennicisms may be fun and useful, particularly in situations where there is no Standard Swedish equivalent to a Finnish word. These are demonstrated in Examples 5-9. Although the responses in Examples 5, 6, and 7 all indicate that the participants believe that fennicisms can be useful, the comments in Examples 6 and 7 also specify that the respondents only consider these features to be appropriate in informal speech contexts. Example 6 also highlights the belief that one must know the "proper" word, even if one chooses to use fennicisms or other finlandisms in casual speech. 
5. Ibland väldigt beskrivande och behändiga.

Somethimes very descriptive and useful.

(Bilingual female, Birkaland)

6. Att använda direktöversätta uttryck (typ att falla av kärran) kan vara ett ganska roligt sätt att använda språket, fram för mera av det! Klart man måste undvika dom i officiella texter, men i talspråk och lediga situationer kan de passa "som knytnäven i ögat". To use directly translated expressions (such as to fall off the wagon) can be a fun way of using the language, by expanding it! Of course one has to avoid them in official texts, but in spoken language and informal situations they can fit like "a fist in the eye".

(Bilingual female, Nyland)

7. I talspråk är det ok och t.o.m. en del av det normala att använda dessa uttryck. Men man bör också veta hur det heter "på riktigt".

In casual speech it's OK and part of the normal to use these expressions. But one must also know what something is "actually" called.

(Monolingual female, Nyland)

8. Jag tycker att finska lånord i finlandssvenskan gör språket mer levande och unikt.

Dessutom tillåter lånord mig att uttrycka mig mer nyanserat eftersom vissa ord och uttryck inte går att översätta till svenskan (t.ex. ordet sisu).

I think that Finnish loanwords in Finland Swedish make the language more lively and unique. Furthermore, borrowed words allow me to express myself with more nuance, because some words and phrases cannot be translated to Swedish (e.g., the word sisu).

(Bilingual female, Nyland)

9. Om ett ord på svenska låter högtravande och är svårt att förstå, översätt till finska och du förstår betydelsen mycket bättre. Mer beskrivande på finska.

If a word sounds pretentious in Swedish and is difficult to understand, translate it to Finnish and you understand its meaning much better. [It is] more descriptive in Finnish.

(Monolingual female, Nyland)

Example 8 indicates that the respondent thinks that fennicisms enrich the Finland Swedish variety, and that they are useful because there is not always an appropriate corresponding word in Standard Swedish. This view is partially mirrored in the response in Example 9, in which a participant states that Standard Swedish may not be descriptive enough, and may be perceived as too pretentious. One participant also explicitly stated that they consider finlandisms part of the Finland Swedish identity, as shown in Example 10:

10. Tycker finlandismer är en del av vår 'språkidentitet', som gör att finlandssvenska skiljer sig från rikssvenska. Det finns dock någon, kanske diffus, gräns enligt mig, efter vilket språket blir 'dålig svenska'.

[I] think that finlandisms are a part of our 'language identity', causing Finland Swedish to differ from Sweden-Swedish. However, according to me there is still some fuzzy line that can be crossed, resulting in 'poor Swedish'.

(Monolingual male, Nyland)

The comment in Example 10 indicates that the participant considers words and phrases specific to Finland Swedish part of his linguistic identity. Although the participant uses the hypernym finlandism, the fact that the comment was encouraged by a question specifically about finlandisms with Finnish influence suggests that the response refers at least partially to finlandisms of Finnish origin. Examples 11 and 12 also show the responses of two speakers who noted that most Finland Swedes may not even realise all the loanwords that they use in everyday speech. 
11. De flesta lånord från finskan $i$ [sic] så vanliga i dagligt tal att man märker dem först då man talar med rikssvenskar som inte förstår orden och uttrycken.

Most Finnish loanwords are so common in everyday speech that one only notices them when speaking with Swedes who do not understand the words and expressions.

(Monolingual female, Nyland)

12. Jag tror att vi använder en massa finska lånord och översättningar som vi inte förstår kommer från finskan.

I think we use many Finnish loanwords and loan translations that we don't understand come from Finnish.

(Monolingual female, Finland Proper)

Although the responses to the open question showed a higher number of positive comments about the diversity and uniqueness of using fennicisms than negative comments, the participants seemed to agree that this type of language is non-standard and should only be used in informal circumstances, usually only in casual speech. Even the positive responses remark that in certain circumstances the use of fennicisms or finlandisms can result in language that is not consider proper or correct Swedish.

\section{Discussion}

The aim of the study was to examine the use of and attitudes of Finland Swedish individuals to finlandisms, in particular words of Finnish origin, or words which persist in the Finland Swedish variety due to parallel use in Finnish. From a language contact perspective, fennicisms are particularly interesting finlandsms: not only are finlandisms of Finnish origin in particularly wide use in Finland Swedish as a result of the extensive contact between Finnish and Swedish, but they are also associated with particular controversy due to the linguistic imbalance in the country. As a result of Finnish being the dominant language in society, fennicisms are often considered particularly threatening to the Finland Swedish variety. In order to explore both the use of and attitudes towards fennicisms, participants were asked to indicate recognition or active use of some words and phrases found in existing sources, as well as encouraged participants to provide their own examples and opinions.

The results of the study indicated that the vast majority of respondents recognised the finlandisms influenced by Finnish that they were presented with. This was particularly true for the direct loanwords, although the majority of loan translations and translated phrases also received a relatively high recognition percentage. It is notable that respondents consistently indicated considerably lower percentages of active use of the fennicisms than recognition of them. While this may be largely due to the fact that many speakers have heard others use a number of fennicisms that they would not use themselves, it may be also be a reflection of the general perception that these are non-standard or erroneous forms. As participants may perceive the use of fennicisms as innately problematic, they may under-report their own use of such features. This belief is reflected in the open responses which voice concern for the increased use of fennicisms, stating that they avoid fennicisms in their own speech.

The survey respondents were prompted to give their own examples of loanwords, loan translations, and translated phrases. The category of loanwords received by far 
the highest number of responses, with as many as 66 unique (perceived) fennicisms. This mirrors findings from previous studies (Melin-Köpilä, 1996; af HällströmReijonen, 2011), which suggest that lexical finlandisms and, in particular, Finnish loandwords are some of the most salient finlandisms. These features have been shown to be the ones that are easiest to avoid in careful speech or writing, and are thus also the easiest to retrieve from memory. By contrasts, survey respondents gave far fewer examples of loan translation and translated phrases.

In spite of the prominence and widespread use of fennicisms, there is a lack of comprehensive literature relating to fennicisms. Fennicisms are largely discussed as only one subtype of finlandisms, and as such there are no comprehensive sources that detail the fennicisms in wide use in Finland Swedish today. This oversight may partially relate to how volatile the use of Finnish words is in Finland Swedish. Considering the high number of fluent or near-fluent bilingual Finnish- and Finland Swedish speakers, it is difficult to differentiate between established loanwords and code-switching between the two languages. By obtaining examples of Finnish words that were reportedly used or observed by several of the survey participants in Finland Swedish, we attempted to identify previously overlooked fennicisms in the Finland Swedish variety. Examples of loanwords that were repeatedly reported but which are seldom discussed in literature include, amongst others, hurja, makee, jännä, karkki, kaukosäädin, kännykkä, and paha. Given that these words were repeated by a number of the survey participants, they are unlikely to represent the code-switching of single individuals, but can rather be presumed to be somewhat established in casual Finland Swedish speech. A few other example words provided by the participants also demonstrate evidence of long-time use; juttu and kaveri have been active in the Finland Swedish vocabulary since at least the 1980s, when they were reported by Liljestrand (1983; 1985). This indicates that fennicisms also persist for an extended amount of time in Finland Swedish, as af Hällström (2010) concluded with regards to finlandisms in general. Although the respondents provided fewer examples of loan translations and translated phrases than direct Finnish loanwords, notable examples that we have not been able to find in previous literature include the loan translation hönshud and the phrase helt samma.

Another factor which makes it challenging to research fennicisms is the fact that it is not always straightforward to determine whether or not a word should be classified as a fennicism. The reality that it is often difficult to definitively establish whether a word or phrase has been borrowed from Finnish to Finland Swedish or vice versa is made evident by the fact that even the Finland Swedish Dictionary does not attempt to provide etymologies for these finlandisms. The matter is further complicated by the fact that many words which have similar forms in Finnish and Finland Swedish can be perceived to be fennicisms, but their origin may be from a third language, or the Finnish cognate may have helped to preserve an archaic Swedish form in the Finland Swedish variety. A considerable number of words presumed to be of Finnish origin may simply have entered Finland Swedish through Finnish, and have likely remained in use due to the parallel existence in both languages. As these words remain in use due to the influence of Finnish, they can be argued to be a type of extended fennicisms. It is notable that the three 
loanwords that were presented most often in the responses as direct fennicisms, i.e., rosk, moj, and vessa belong to the group of words having similar forms in Finland Swedish and Finnish, but which have another origin language. One of the most common finlandisms, rosk, is often associated with or attributed to its Finnish equivalent, despite its Norse origin (see af Hällström-Reijonen, 2018).

The responses regarding attitudes towards incorporating Finnish loanwords in Finland Swedish likewise suggest a conflicting relationship between individuals and their language use. Some participants perceive the use of finlandisms and fennicisms as markers of a specifically Finland Swedish identity, differentiating them from the Swedish speakers in Sweden. On the other hand, the use of fennicisms can also be perceived as inherently erroneous, and was argued by one respondent to contribute to what they considered to be the decline of Swedish in Finland. Furthermore, although several responses to the open question indicated that they found fennicisms fun or useful, the comments also highlighted the fact that these forms are not considered appropriate in formal contexts. These open responses, along with the survey results indicating a preference for reporting exposure to rather than use of fennicisms, suggest that there is a certain stigma attached to using fennicisms and finlandisms in general in the Finland Swedish variety. The use of fennicisms and finlandisms seems to be consistently deemed problematic, as even the participants who made positive comments about fennicisms wished to point out that they were aware that these types of words are not considered "proper Swedish."

Although the present study has examined the use of Finland Swedish words and phrases influenced by Finnish in a novel fashion, the survey data exhibit a few shortcomings. Both the gender and regional distributions were unbalanced, with the vast majority of participants being female, and more than half stemming from the region of Nyland in Southern Finland. While the latter fact may be partially explained by the the high population density in Nyland (Statistics Finland, 2021), more responses from other areas would give a clearer picture of regional distribution of fennicisms. A second limitation is the fact that data on the participants' ages were not collected in the survey. While previous research indicates that finlandisms are widespread and largely independent of speakers' age, gender, or socioeconomic and regional background, fennicisms have not been examined in great detail, meaning that potential variation could be present for these specific finlandisms. As results by Tandefelt (2007) suggest that younger speakers are more lenient towards using Finnish words in Finland Swedish, a factor of age may correlate with the frequency of fennicisms. Furthermore, given that contact with the Finnish majority language varies depending on the Finland Swedish region, with fluent bilingualism being particularly common in Southern Finland but more rare in Ostrobothnia (see Finnäs, 2012), regional background could also be expected to influence the use of fennicisms. Forsskåhl (2015:57) states that slang words based on Finnish are much more commonly found in Finland Swedish used by individuals in Finnish-majority regions; as such, the results of the current study may give a more accurate indication of fennicisms that are used in Southern Finland, but may not be fully representative of ones used in Ostrobothnia. In future studies, a larger sample size with a broader examination of regional variation, as well as the inclusion of age as a factor, would allow for more detailed evaluation of fennicisms in use. 
A larger sample size would also enable the collection of more examples of fennicisms, and, most importantly, of more repetitions of words. From the current data, where many words and phrases only occur once or twice, it is difficult to glean whether some of the fennicisms are in wider use in the population, or simply appear in the speech of certain individuals.

A final limitation of the survey which warrants mentioning is the metalinguistic awareness that is required for respondents to provide their own examples of loanwords, loan translations, and translated phrases. The participants were required to actively consider potential Finnish influence on words or phrases that they use or have noticed others using, rather than producing the forms spontaneously. Additionally, the triggering of metalinguistic awareness by providing examples, combined with the general public perception of fennicisms as problematic, means that participants may have been more inclined to under-report the number of fennicisms they use, compared to the ones they reportedly recognised.

\section{Conclusion}

The survey responses in the present study demonstrate contradictory attitudes by Finland Swedes towards their native variety. The responses indicate that finlandisms can be considered a part of their linguistic identity as Swedish speakers in Finland, reflecting similar positive sentiments to those identified by Tandefelt (2007) and Bergroth (2016). Responses to the current study also indicate that even fennicisms are often viewed as fun and useful features that can be used to enrich the variety. Yet, despite such positive comments, most participants agree that the use of fennicisms is only appropriate in informal contexts, and it is considered crucial that speakers know what something is called in "proper Swedish." Four participants also stated adamantly that they avoided any non-standard Finland Swedish forms. Regardless, survey responses to the examples of loanwords, loan translation, and translated phrases indicated that most participants actively use and recognise words and phrases originating in or influenced by Finnish. Additionally, the survey responses provided evidence a wide range of fennicisms in use in Finland Swedish, some of which have not been recorded in previous literature. These findings as a whole suggest a conflicting relationship between Finland Swedish speakers and their language use. Individuals are faced with a sense of obligation to maintain their language and avoid finlandisms, while simultaneously finding them useful. Furthermore, in spite of evidence suggesting a wide range of Finnish influence on the Swedish spoken in Finland, fennicisms seem to be continuously thought of as the most problematic type of finlandism.

\section{Notes}

1 The territory of Finland was ruled by Sweden from the 12th to the 19th century; although Finland became part of the Russian Empire in 1809, Swedish continued to be the administrative language until the second half of the 19th century (see, e.g., McRae et al., 1997).

2 In this article, we refer to the Swedish variety spoken in Finland as 'Finland Swedish', and to its speakers as 'Finland Swedes'. Alternative forms that the reader may encounter in other sources are 'Fenno-Swedes' and 'Swedish-speaking Finns'. 
3 Abbreviations for parts-of-speech largely follow the Leipzig Glossing Rules (2015), i.e., adj.=adjective; adv. $=$ adverb; $\mathrm{n} .=$ noun; $\mathrm{v} .=$ verb; excl. = exclamation.

4 It should be noted that, although the compound word bakbänk is a Finland Swedish loan translation of Finnish takapenkki, the Finnish word penkki, meaning 'bench', has itself originally been borrowed from the Swedish word bänk (Oksanen, 2006).

5 The word skyddsväg has previously been found in Finland Swedish legal texts, but the Institute for Languages in Finland recommends that the word övergångsställe is used (Finlandssvensk ordbok).

6 In 2020, approximately 30 percent of the Finnish population (i.e., 1702678 individuals) lived in Nyland (Statistics Finland, 2021).

7 The word morjens has been attested as an informal Swedish greeting based on morgon since at least 1847 (Svenska.se), and the use of moro/moi in Finnish is usually attributed to contact with Swedish. Other possible explanations include influence from Low German moin via seafaring trade; however the origins of Finnish moi and Finland Swedish moj/mojn continue to be debated.

\section{References}

Aapala, Kirsti. 1997. Leivät ja leivonnaiset. Kielikello, 4/1997. https://www.kielikello.fi/-/leivat-jaleivonnaiset (accessed 2 February 2021).

Bergroth, Hugo. 1917. Finlandssvenska: Handledning till undvikande av provincialismer i tal och skrift. Helsinki.

Bergroth, Mari. 2016. Mielummin kurabyxor kuin galonbyxor: Tvåspråkiga familer och språk i vardagen. In Jaana Kolu, Mikko Kuronen \& Åsa Palviainen (eds.), Svenskan i Finland 16, 9-23. Jyväskylä: Jyväskylä studies in Humanities 298.

Clyne, Michael, Catrin Norrby \& Jane Warren. 2009. Language and human relations: Styles of address in contemporary language. Cambridge: Cambridge University Press.

Finlandssvensk ordbok. Institutet för de inhemska språken. http://kaino.kotus.fi/fsob/ (accessed 2 February 2021).

Finnäs, Fjalar. 2012. Finlandssvenskarna 2012: en statistisk rapport. Svenska Finlands folkting.

Finnäs, Fjalar. 2015. Tvåspråkiga familjer och deras betydelse för demografin. In Marika Tandefelt (ed.), Gruppspråk, samspråk, två språk. Svenskan i Finland, i dag och i går I:2, 201-220. Helsinki: Svenska litteratursällskapet i Finland.

Forsskåhl, Mona. 2015. Finlandssvensk slang. In Marika Tandefelt, Gruppspråk, samspråk, två språk. Svenskan i Finland - $i$ dag och $i$ går I:2, 47-90. Helsinki: Svenska litteratursällskapet i Finland.

Helgason, Pétur, Ringen Catherine \& Kari Suomi. 2010. Quantity in Central-Swedish and Fenno-Swedish. Working Papers 54. In S. Schötz and G. Ambrazaitis, Proceedings from Fonetik 2010, Lund, June 2-4, 2010 (pp. 47-50).

Helgason, Pétur, Ringen Catherine \& Kari Suomi. 2013. Swedish quantity: Central Standard Swedish and Fenno-Swedish. Journal of Phonetics, 41(6), 534-545. https://doi.org/10.1016/j.wocn.2013.09.005

af Hällström, Charlotta. 2000. Definitioner på några termer som används i språkvårdslitteratur. Språkbruk, $1 / 2000,13-15$.

af Hällström-Reijonen, Charlotta. 2010. Ett sekel av kamp mot finlandismer: Tre försök att mäta språkvårdens effekt. Maal och minne 102(2), 102-133.

af Hällström-Reijonen, Charlotta. 2011. Finlandismer i akademiska föredrag. Språk \& stil, 21, 58-80.

af Hällström-Reijonen, Charlotta. 2012. Finlandismer och språkvård från 1800-talet till idag. Nordica Helsingensia, 28. University of Helsinki.

af Hällström-Reijonen, Charlotta. 2018. På Färöarna heter roskisbilen ruskbilur. Språkbruk, 4/2018. https://www.sprakbruk.fi/-/pa-faroarna-heter-roskisbilen-ruskbilur (accessed 2 February 2021).

af Hällström-Reijonen, Charlotta, \& Mikael Reuter. 2000. Svar till Kristina Nikula. LexicoNordica 7, $262-264$.

Häkkinen, Kaisa. 2019. Svenska lånord i finskan. In Marika Tandefelt (ed.), Finländsk svenska från medeltid till 1860. Svenskan i Finland - I dag och i går III:1, 385-398. Helsinki: Svenska litteratursällskapet i Finland.

Jamrowska, Julita. 1996. Finskans inflytande på svenskan de senaste 20 åren. Folia Scandinavica, 3, 311-316. 
Kolehmainen, Taru. 2007. Moi taas! Kotimaisten kielten keskus, 8 April 2007. https://www.kotus.fi/nyt/ kolumnit_artikkelit_ja_esitelmat/kuukauden_kielijuttu_\%282003_2011\%29/moi\%21 (accessed 14 June 2020).

Kotus.fi. Sanojen alkuperästä: Palaveri. Kotimaisten kielten keskus. https://www.kotus.fi/nyt/kysymyksia ja_vastauksia/sanojen_alkuperasta/palaveri (accessed 6 October 2020).

Kuntaliitto.fi 2017. Ruotsin- ja kaksikieliset kunnat. https:/www.kuntaliitto.fi/sites/default/files/media/file/ 2017-02-ruotsin-ja-kaksikieliset-kunnat_0.pdf (accessed 08 June 2021).

Kuronen, Mikko. 2001. Acoustic character of vowel pronunciation in Sweden-Swedish and Finland Swedish. Working Papers 49 (2001), 94-97. Lund University Department of Linguistics.

Kuronen, Mikko \& Kari Leinonen. 2001. Fonetiska skillnader mellan finlandssvenska och rikssvenska. Svenskans beskrivning 24: Förhandlingar vid Tjugofjärde sammankomsten för svenskans beskrivning, 006, 125-138. Linköping: Linköping University Electronic Press.

Kuronen, Mikko \& Kari Leinonen. 2011. Historiska och nya perspektiv på svenskan i Finland. Tampere: Juvenes Print.

Laureys, Godelieve. 2013. Vem äger svenskan? Pluricentriska språk och frågan om ownership och stakeholdership. In Jan Lindström, Sofie Henricson, Anne Huhtala, Pirjo Kukkonen, Hanna Lehti-Eklund \& Camilla Lindholm (eds.), Svenskans beskrivning 33, 233-245.

Leipzig Glossing Rules. 2015. Leipzig Glossing Rules: Conventions for interlinear morpheme-bymorpheme glosses. https://www.eva.mpg.de/lingua/pdf/Glossing-Rules.pdf (accessed 2 February 2021).

Liebkind, Karmela, Marika Tandefelt \& Tom Moring. 2007. Introduction: Why a special issue on the Swedish-speaking Finns? International Journal on the Sociology of Language 187/188, 1-11. https:// doi/10.1515/IJSL.2007.047

Liljestrand, Birger. 1983. Keikka och pilkhalare: Något om finlandssvenskt tidningsspråk. Språkbruk, $2 /$ 1983, 4-17.

Liljestrand, Birger. 1985. Juttu och sammetsfarmare: Notiser om finlandssvenskt språkbruk. Skrifter utgivna av Institutionen för nordiska språk vid Umeå universitet.

Lindström, Jan. 2009. Negationen inte i satsens spets. In Wide \& Lyngfelt (eds.), 163-192.

Mansikka, Sanna. 2018. Kaffeporo och kaffesump: om användning av ett urval finlandssvenska och sverigesvenska matord. MA dissertation, University of Tampere.

Martola, Nina. 1992. Arbetet med Finsk-svensk ordbok: Normeringsproblem visavi finlandssvenskan. Nordiske Studier i Leksikografi 1, 515-521.

McRae, Kenneth, Mika Helander, \& Sari Luoma (1997). Conflict and compromise in multilingual societies: Volume 3, Finland. Wilfrid Laurier University Press.

Melin-Köpilä, Christina. 1996. Om normer och normkonflikter i finlandssvenskan. Ph.D. dissertation, University of Uppsala. Skrifter utgivna av Institutionen för nordiska språk vid Uppsala universitet, 41.

Oksanen, Sanna. 2006. Penkiltä pankolle. Kielikello: Kielenhuollon tiedotuslehti, 3/2006. https://www. kielikello.fi/-/penkilta-pankolle (accessed 4 October 2019).

Reuter, Mikael. 1986. Tala om tur... Reuters ruta, 12/10 1986. https://www.sprakinstitutet.fi/sv/ publikationer/sprakspalter/reuters_rutor_1986_2013/1986/tala_om_tur_... (accessed 8 June 2021).

Reuter, Mikael. 1987a. Vad är finlandssvenska? Språkbruk, 1/1987, 3-10.

Reuter, Mikael. 1987b. Med långa tänder inför riksdagsvalet. Reuters ruta, 13/3 1987. https://www.kotus.fi/ sv/publikationer/sprakspalter/reuters_rutor_1986_2013/1987/med_langa_tander_infor_riksdagsvalet (accessed 8 October 2019).

Reuter, Mikael. 1989. Be om ordet på efternatten. Reuters ruta, 30/6 1989. https://www.kotus.fi/sv/ publikationer/sprakspalter/reuters_rutor_1986_2013/1989/be_om_ordet_pa_efternatten (accessed 8 October 2019).

Reuter, Mikael. 1991a. Svart expert gör värnplikt. Reuters ruta, 3/5 1991. https://www.sprakinstitutet.fi/sv/ publikationer/sprakspalter/reuters_rutor_1986_2013/1991/svart_expert_gor_varnplikt (accessed 8 June 2021).

Reuter, Mikael. 1991b. Swedish as a pluricentric language. In Michael Clyne, Pluricentric Languages, 101-116. Berlin, Boston: De Gruyter Mouton.

Reuter, Mikael. 2005. Finns det en finlandssvensk språknorm? Språk i Norden 2005, 97-106.

Reuter, Mikael. 2007. Reuters rutor 3. Språkspalter om ord och ordanvändning. Helsinki: Schildts.

Reuter, Mikael. 2015a. Finlandssvenskt uttal. In Marika Tandefelt (ed.) Gruppspråk, samspråk, två språk. Svenskan i Finland - I dag och i går I:2, 19-30. Helsinki: Svenska litteratursällskapet i Finland. 
Reuter, Mikael. 2015b. Så här ska det låta: Om finlandssvenska och språkriktighet. 2nd Edition. Helsinki: Scriptum.

Reuter, Mikael, Charlotta af Hällström-Reijonen \& Marika Tandefelt. 2017. Finlandismer i skriven finlandssvenska. In Marika Tandefelt (ed.), Språk i prosa och press. Svenskan i Finland - I dag och i går II:1, 16-27. Helsinki: Svenska litteratursällskapet i Finland.

Sandström, Caroline \& Charlotta af Hällström-Reijonen. 2015. Behandling av långlivade finlandismer i SAOB - ett finländskt perspectiv. In Birgit Eaker, Birgitta Hedbäck, Lennart Larsson, Pär Nilsson \& Christina Persson (eds.), Ord och gärning, 122-141. Stockholm: Svenska Akademien.

Smith, William G. 2008. Does gender influence online survey participation? A record-linkage analysis of university faculty online survey response behaviour. https://files.eric.ed.gov/fulltext/ED501717.pdf (accessed 24 June 2021).

Språkbanken (n.d.). KORP v9. https://spraakbanken.gu.se/korp/ (accessed 24 June 2021).

Språkbanken i Finland (n.d.). The Language Bank of Finland. https://www.kielipankki.fi/sprakbanken/ (accessed 2 February 2021).

Statistics Finland. 2021. Väestö. https://www.tilastokeskus.fi/tup/suoluk/suoluk_vaesto.html. (accessed 8 June 2021).

Strandberg, Janine A.E. 2018. An acoustic analysis of generational change of the open-mid front rounded vowel [o] in Finland-Swedish. MA dissertation: Leiden University.

Strandberg, Janine A.E., \& Charlotte Gooskens. in press. Bilingualism, ideology, and identity: Change in the Finland-Swedish variety. In Dick Smakman, Jirí Nekvapil, \& Kapitolina Fedorova (Eds.), Linguistic choices in the contemporary city: Postmodern individuals in urban communicative settings. London, UK: Routledge.

Strandberg, Janine A.E., Charlotte Gooskens \& Anja Schüppert. 2021. Simultaneous bilingualism and speech style as predictors of variation in allophone production: Evidence from Finland-Swedish. Journal of Phonetics, 88, 101095. https://doi.org/10.1016/j.wocn.2021.101095

Svenska.se (n.d.) Svenska akademiens ordböcker. https://svenska.se/ (accessed 20 January 2021).

Tandefelt, Marika. 1996. På vinst och förlust: om tvåspråkighet och språkförlust i Helsingforsregionen. Forskningsrapporter 35. Helsinki: Svenska Handelshögskolan.

Tandefelt, Marika. 2007. 887 sätt att se på svenskan i Finland: En redogörelse för en webbenkät genomförd hösten 2002. Swedish School of Economics and Business Administration Research Reports. Helsinki: Svenska handelshögskolan.

Tandefelt, Marika \& Fjalar Finnäs. 2007. Language and demography: Historical development. International Journal on the Sociology of Language 187/188, 35-54. https://doi/10.1515/IJSL.2007.049

Thompson, Della. 2009. Oxford Essential Russian Dictionary. Oxford: Oxford University Press.

Thylin-Klaus, Jennica. 2019. Svensk språkvård i Finland 1880-1917. In Marika Tandefelt (ed.), Finländsk svenska från 1860 till nutid. Svenskan i Finland - I dag och i går III:2, 67-98. Helsinki: Svenska litteratursällskapet i Finland.

Vikør, Lars. S. 2010. Language purism in the Nordic countries. International Journal of the Sociology of Language 2010(204), 9-30. https://doi/10.1515/ijsl.2010.028

Vilppula, Matti. 2001. Kiva - ett ord från Kajanaland. Språkbruk, 1/2001.

Wide, Camilla \& Benjamin Lyngfelt (eds.). 2009. Konstruktioner i finlandssvensk syntax: Skriftspråk, samtal och dialekter. Helsinki: Svenska litteratursällskapet i Finland.

Wide, Camilla \& Benjamin Lyngfelt. 2009. Svenskan i Finland, grammatiken och konstruktionerna. In Wide \& Lyngfelt (eds.), 11-46.

Äikäs, Monica. 2012. Språkfrågor. Språkbruk, 4/2012. https://www.sprakbruk.fi/-/sprakfra-12 


\section{Appendix}

The Appendix contains Table 13, which shows the origins of the loanwords perceived by participants as direct fennicisms, but which have other origins.

Table 13. Origins of loanwords perceived as direct fennicisms

\begin{tabular}{llll}
\hline Finland Swedish & Finnish & Source & Translation \\
\hline acku, akku n. & akku & Finland Swedish slang & 'battery' \\
\hline (värme)batteri n. & (lämpö)patteri & batterie (French) & 'radiator' \\
\hline butka, n. & putka & butka (Russian) & 'jail, prison' \\
\hline dragkedja, n. & vetoketju & alternative & 'zipper' \\
\hline halare, haalare, n. & haalari & hala (Swedish) & 'overalls' \\
\hline knackkorv n. & nakkimakkara & Knackwurst (German) & 'frankfurter' \\
\hline krapula n. & krapula & crapula (Latin) & 'hangover' \\
\hline leffa n. & leffa & levande bilder (Swedish) & 'movie, cinema' \\
\hline moj, mojn, moi & moi, moikka & morgon, morjens (Swedish) & 'Hi, Hello' \\
\hline pulka, pulkka, n. & pulkka & puhlke (Sámi) & 'sled' \\
\hline rosk, roskis, n. & roska & rosk, rusk (Norse) & 'trash, garbage' \\
\hline semla, n. & sämpylä & Semmel (German) & 'bread roll' \\
\hline spåra, n. & spora & spårvagn (Swedish) & 'tram' \\
\hline stöpsel, n. & töpseli & Stöpsel (German) & 'electrical chord' \\
\hline vessa, n. & vessa & WC (English) & 'toilet' \\
\hline ämbar, n. & ämpäri & archaism & 'bucket' \\
\hline
\end{tabular}

Cite this article: Strandberg JAE, Gooskens C, and Schüppert A. Errors or identity markers? A survey study on the use of and attitudes towards finlandisms and fennicisms in Finland Swedish. Nordic Journal of Linguistics. https://doi.org/10.1017/S0332586521000317 